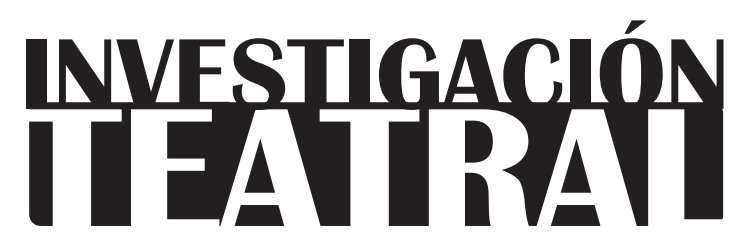

Revista de artes escénicas y performatividad

Vol. 12, Núm. 19

abril-septiembre 2021

Segunda época

ISSN impreso: $1665-8728$

ISSN electrónico: 2594-0953

Universidad Veracruzana
In memoriam

\section{Mónica Kubli, Félida Medina y Marcela Zorrilla. Tres escenógrafas mexicanas, su legado}

\author{
Patricia Ruiz Rivera*
}

Recibido: 17 de noviembre de 2020

Aceptado: 01 de marzo de 2021

Doi: $10.25009 /$ it.v12i19.2665 


\section{Mónica Kubli, Félida Medina y Marcela Zorrilla. Tres escenógrafas mexicanas, su legado}

$\mathrm{E}$ año 2020 será recordado por una serie de acontecimientos desafortunados, como la ola de muerte por la transmisión a nivel mundial de Covid-19, que había causado más de 180 mil fallecimientos tan solo en México hacia febrero de 2021; en este país, los decesos de reconocidos artistas han sido dolorosos. Han muerto, por causa de esta enfermedad, Cecilia Romo, Óscar Chávez, Raymundo Capetillo, Pilar Pellicer, Rogerio Baruch y, por otras causas, José Luis Ibáñez, Héctor Suárez, Héctor Ortega, Mónica Miguel, Aarón Hernán, Jaime Humberto Hermosillo, Manuel Felguérez y, desafortunadamente, un largo etcétera.

Las escenógrafas mexicanas Mónica Kubli, Félida Medina y Marcela Zorrilla también fallecieron en el 2020, por lo que es momento de reconocer el valiosísimo legado que dejaron al teatro mexicano. Desde su incursión en el campo, estas tres creadoras trabajaron incansablemente, formando profesionales para la renovación de la escena nacional, especializándolos en la iluminación, escenografía y producción escénica. ${ }^{1}$

Mónica Kubli (1957-2020) fallece el 22 de marzo, víctima de cáncer. Gran iluminadora y escenógrafa, formada bajo la tutela de Ludwik Margules y Alejandro Luna (de quien es asistente durante un tiempo), egresa del Centro Cultural Universitario en 1986. Comienza a trabajar para la danza y se convierte en una gran ambientadora de obras coreográficas (trabaja con Raúl Parrao, Alicia Sánchez y Pilar Medina, entre otros coreógrafos); a partir

1 Para revisar el campo escenográfico, se recomienda: Recchia, Giovanna. Escenografía mexicana del siglo XX. México: Conaculta, fonca, Cenart, inba, Citru, 1999. 
de 2001, es la iluminadora del bailarín y coreógrafo japonés Ko Murobushi en sus presentaciones en México, hasta su muerte en 2015. Fundadora junto con Nina Serratos en 1993 del Teatro de la Oca, recibe la beca de ejecutante del Consejo Nacional para la Cultura y las Artes (CONACUlTa) ese mismo año.

Trabaja para cine y televisión, formatos que le permiten explorar como directora de arte y ambientadora. Para 2009, Alberto Estrella y Víctor Carpinteiro la invitan a colaborar en El círculo teatral, donde le permiten dar rienda suelta a la experimentación en el diseño y la ambientación, incorporando video o elaborando espacios muy realistas o abstractos para la representación. ${ }^{2}$ Su última participación como creadora es para la obra El consultorio de la Dra. Spellman, que se estrena el 16 de febrero y que suspende funciones debido a la pandemia. Al ser una especialista en iluminación escénica, Kubli imparte cursos y conferencias en varias ciudades de la República Mexicana, a lo largo de su vida creativa.

Félida Medina (1941-2020) muere el 24 de marzo, víctima de cáncer. Originaria de Temascaltepec, Estado de México, decide inscribirse, en 1963, en la única escuela que contaba con la carrera de Escenografía en aquel entonces: la Escuela de Arte Teatral (EAT). Tener contacto con maestros como Leoncio Nápoles, Antonio López Mancera, Ignacio Zúñiga y Julio Prieto, le abre un amplio panorama para expresarse a través de su imaginación. Da sus primeros pasos como escenógrafa en la Temporada de teatro popular al aire libre en 1963, siendo aún alumna, y posteriormente trabaja con el director Virgilio Mariel en El principito (1966-1969), en la Casa de la paz, que le vale el primero de muchos premios que, a lo largo de su trayectoria, recibió por parte de asociaciones de críticos del medio teatral. Quizá, de los cerca de 130 montajes profesionales en los que participa a lo largo de su vida profesional, sus creaciones más icónicas sean Cementerio de automóviles (dir. Julio Castillo, 1968), Los albañiles (dir. Ignacio Retes, 1969), El extensionista (dir. Felipe Santander, 1978) o Escarabajos (dir. Hugo Rentería, 1991). Buscando ese estilo propio de interpretar dentro del escenario, a la par de iniciar como docente en la EAT en 1970, la entonces joven Félida se arriesga con ideas que ya le rondan en la cabeza y le van permitiendo audacias con la creación de atmósferas a través de desniveles y pantallas de video en el escenario, como en el montaje de El juicio (dir. Ignacio Retes, 1971) y que perfeccionará tiempo después, al ser la primera en utilizar estructuras tubulares o acrílicos en el escenario.

Llega a trabajar con estilos muy distintos de dirección: Clementina Otero, Dagoberto Guillaumin, Miguel Sabido, Willebaldo López, Julio Castillo, Ignacio Retes, Xavier

2 Algunas imágenes del trabajo escénico de Mónica Kubli se puede ver en la página de El Círculo teatral, en https://www.facebook.com/elcirculoteatral/videos/635329503982857 
Rojas, Marco Antonio Montero, Dimitrios Sarrás, Nancy Cárdenas, Blas Braidot, Felipe Santander, entre muchos otros, a lo largo de sus casi 50 años como profesional. Como docente imparte cursos y seminarios sobre producción teatral, escenografía y escenotecnia en varias universidades e institutos de la República Mexicana; además, es titular en la carrera de Escenografía, en la Escuela Nacional de Arte Teatral, desde su ingreso como docente, y coordinadora de área en varios periodos, hasta su muerte. Participa en dos ocasiones en la Cuadrienal de Praga, en 1975 y 1995, representando a México como expositora y como presidenta de la Sociedad Mexicana de Escenógrafos, de donde es miembro fundador. ${ }^{3}$

Marcela Zorrilla (1931-2020) fallece el 19 de octubre por causas naturales. Pintora, escenógrafa, vestuarista, asistente de dirección y producción, resalta su labor como docente. Poseedora de una gran sensibilidad para la enseñanza, dedica gran parte de su carrera profesional a la formación de nuevos profesionales en las artes escénicas, pues una de sus clases más emblemáticas fue Producción escénica, impartida tanto para la Facultad de Filosofía y Letras de la UNAM como para la carrera de Escenografía en la EAT. En 1951 egresa de la carrera de maestro en artes plásticas en la UNAM y con esa formación de pintora, le atrae la escenografía y se relaciona tomando cursos tanto en la EAT como en la UNAM.

Asimismo, no deja de largo su faceta como pintora y su actividad profesional en ese rubro incluye numerosas exposiciones en las que participa de manera colectiva e individual entre 1951 y 1991. Se inicia como escenógrafa en el teatro universitario colaborando con el maestro Héctor Azar, en el Teatro de Coapa. Apoya, en el teatro universitario, el trabajo de siete directores jóvenes, entre los que se encuentran Ludwik Margules, Miguel Sabido, Juan Felipe Preciado e Ignacio Sotelo. En 1964 gana el premio a mejor vestuario y maquillaje en Nancy, Francia, con el montaje de Divinas palabras, de José Luis Ibáñez. Es miembro de la Compañía de Repertorio de Teatro Universitario y en 1969 es becada para estudiar historia del teatro, historia del traje y escenografía en Francia e Italia. A su regreso se integra al mundo laboral como escenógrafa, docente y en una faceta que es desconocida por muchos: la de ilustradora de libros y revistas, trabajo que inicia con el libro Italia en México, en 1957; posteriormente, ilustra varios

3 Parte del trabajo de Félida Medina se puede consultar en la Biblioteca digital no. 4 del CITRU:

"Julio Castillo. 'El niño que no me deja en paz"'. YouTube, subido por Citru Bellas Artes, 13 de abril de 2019, https://youtu.be/sXXlABG0bRk, consultado el 1 de marzo de 2021.

"Ignacio Retes. 'Ocupación teatrista”. YouTube, subido por CITRU Bellas Artes, 14 de abril de 2019, https://youtu.be/ravUofujsQA, consultado el 1 de marzo de 2021. 
INVESTIGACIÓNTEATRAL

Revista de artes escénicas y performatividad

Vol. 12, Núm. 19

abril-septiembre 2021
Mónica Kubli, Félida Medina y Marcela Zorrilla.

Tres escenógrafas mexicanas, su legado

Patricia Ruiz Rivera

números más para Textos de teatro, hasta 1977. Elabora material didáctico para las materias de producción teatral (UNAM, 1985, y CEIBA, 1986). Trabaja en varias producciones emblemáticas del teatro contemporáneo mexicano: Olímpica (dir. Juan Ibáñez, 1967), Amor es más laberinto (dir. Ignacio Sotelo, 1983), Botica modelo (dir. Mercedes de la Cruz, 1986), Secretos de familia (dir. Héctor Mendoza, 1991) y Popol-Vuh (dir. Miguel Flores, 1993). En 2014 le entregan el reconocimiento Escuela de Altos Estudios de la UNAM por su impecable labor profesional y docente en las Artes Escénicas y sigue impartiendo clases hasta su jubilación en $2018 .^{4}$

4 Existe una entrevista realizada para la revista Kuchkabal, núm. 18: Zorrilla, Marcela. Entrevista con Sergio Galindo Espinoza. "Entrevista completa a la Maestra Marcela Zorrilla y Velázquez". YouTube, subido por Revista Kuchkabal, https://www.youtube.com/watch?v=RD6h93bxOqg, consultado el 1 de marzo de 2021 . 